\title{
HYDROLOGY AND WATER QUALITY OF THE FOREST COUNTY POTAWATOMI INDIAN RESERVATION, WISCONSIN
}

By R.A. Lidwin and J.T. Krohelski

U.S. GEOLOGICAL SURVEY

Water-Resources Investigations Report 91-4136

Prepared in cooperation with the

FOREST COUNTY POTAWATOMI COMMUNITY OF WISCONSIN

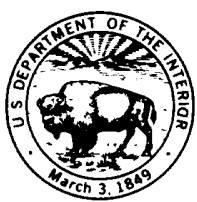

Madison, Wisconsin 


\title{
U.S. DEPARTMENT OF THE INTERIOR \\ BRUCE BABBITT, Secretary
}

\section{U.S. GEOLOGICAL SURVEY}

\author{
Dallas L. Peck, Director
}

District Chief

U.S. Geological Survey

6417 Normandy Lane

Madison, WI 53719
U.S. Geological Survey

Books and Open-File Reports Section

Box 25425, Federal Center

Denver, CO 80225 


\section{CONTENTS}

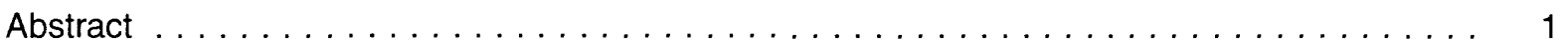

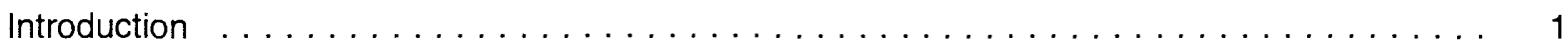

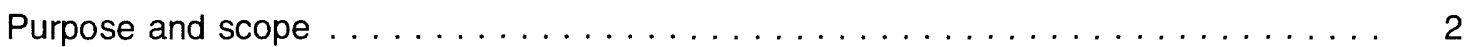

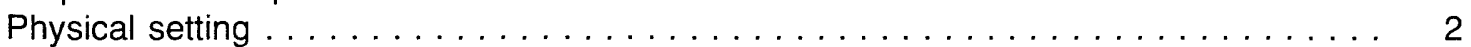

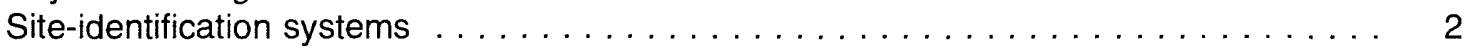

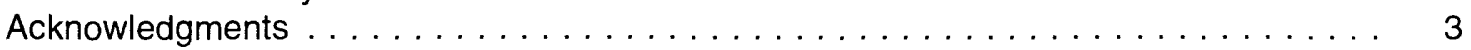

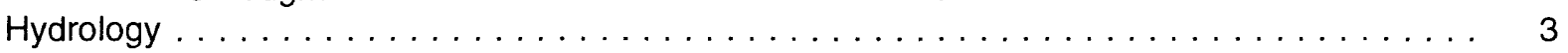

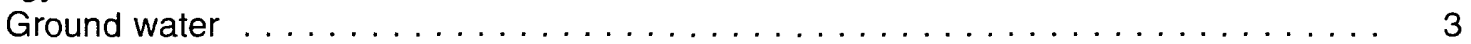

Water-table configuration and saturated thickness $\ldots \ldots \ldots \ldots \ldots \ldots$

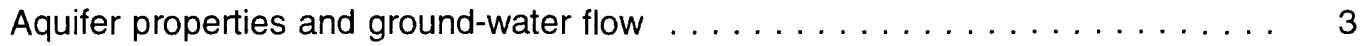

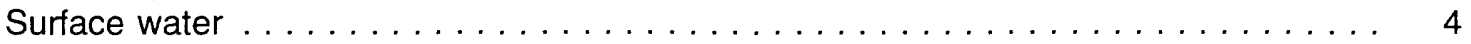

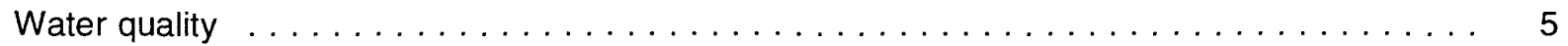

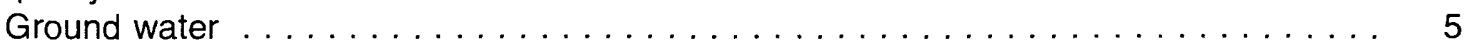

$\mathrm{pH}$, alkalinity, and hardness ..................... 6

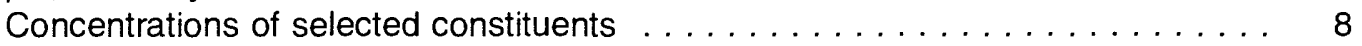

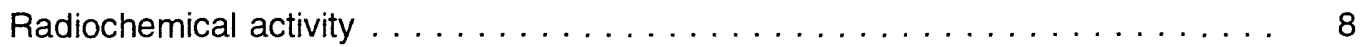

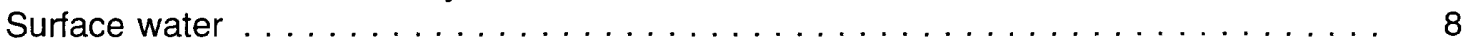

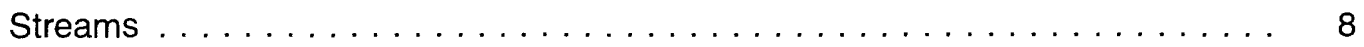

$\mathrm{pH}$, alkalinity, and hardness .................. 8

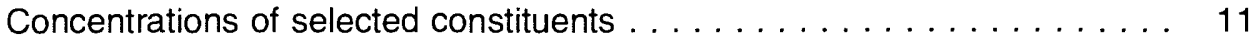

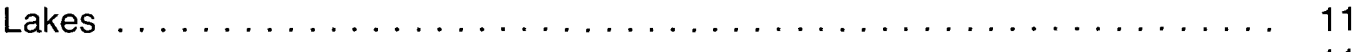

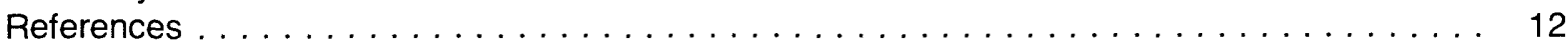

Appendixes

A: Water-level and well-construction data for domestic and observation wells

in the sand and gravel aquifer $\ldots \ldots \ldots \ldots \ldots \ldots \ldots \ldots \ldots \ldots \ldots$

B: Horizontal hydraulic conductivity, well-construction data, and brief description

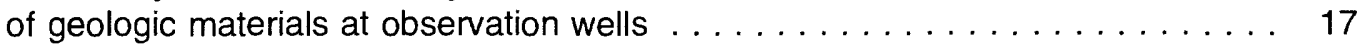

C: Physical and chemical characteristics of water from wells on the

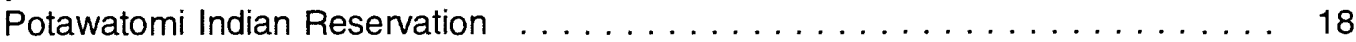

D: Trace-constituent analyses of water from wells on the

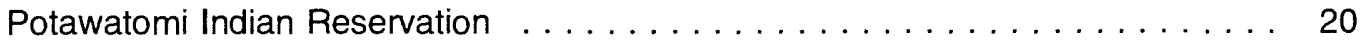

E: Radioactive-particle analyses of water from wells on the

Potawatomi Indian Reservation ........................ 21

F: Physical and chemical characteristics of water from streams on the

Potawatomi Indian Reservation .......................... 22

G: Trace-constituent analyses of bottom material from streams on the

Potawatomi Indian Reservation ...................... 23

$\mathrm{H}$ : Physical and chemical characteristics of water from lakes on the

Potawatomi Indian Reservation ........................ 24 


\section{ILLUSTRATIONS}

[Plates are in pocket]

Plates 1-4. Maps showing:

1. Location of Forest County Potawatomi tribal lands, study area, seismic survey lines, observation wells, domestic wells, bedrock outcrops, and surface-water sampling sites

2. Bedrock topography, Forest County Potawatomi Indian Reservation

3. Altitude of the water table and direction of ground-water flow, Forest County Potawatomi Indian Reservation

4. Saturated thickness of the glacial drift, Forest County Potawatomi Indian Reservation

Figure 1. Modified Stiff diagram showing major-ion concentrations of ground water and stream water of the Potawatomi Reservation . . . . . . . . . . . . . . .

\section{TABLES}

Table 1. Summary of physical and chemical characteristics of water from wells on the Potawatomi Indian Reservation, $1982-83 \ldots \ldots \ldots \ldots \ldots$

2. Summary of trace-constituent analyses of water from wells on the Potawatomi Indian Reservation, $1982-83 \ldots \ldots \ldots \ldots \ldots$

3. Summary of selected U.S. Environmental Protection Agency

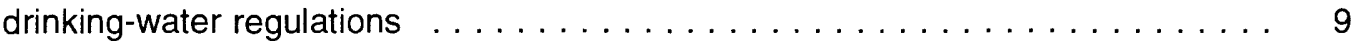

4. Summary of physical and chemical characteristics of water from streams on the Potawatomi Indian Reservation, 1982-83 . . . . . . . . . . . . . 10

5. Summary of trace-element analyses of bottom material from streams on the Potawatomi Indian Reservation, 1982-83 
CONVERSION FACTORS, VERTICAL DATUM, AND WATER-QUALITY UNITS

Multiply

acre

foot $(\mathrm{ft})$

foot per day (ft/d)

cubic foot per second $\left(\mathrm{ft}^{3} / \mathrm{s}\right)$
By

0.004047

0.3048

0.3048

0.02832
To obtain

square kilometer

meter

meter per day

cubic meter per second

Sea level: In this report "sea level" refers to the National Geodetic Vertical Datum of 1929--a geodetic datum derived from a general adjustment of the first-order level nets of the United States and Canada, formerly called Sea Level Datum of 1929.

Abbreviated water-quality units used in this report: Chemical concentrations and water temperature are given in metric units. Chemical concentration is given in milligrams per liter ( $\mathrm{mg} / \mathrm{L}$ ) or micrograms per liter $(\mu \mathrm{g} / \mathrm{L})$. Milligrams per liter is a unit expressing the concentration of chemical constituents in solution as weight (milligrams) of solute per unit volume (liter) of water. One thousand micrograms per liter is equivalent to one milligram per liter. For concentrations less than $7,000 \mathrm{mg} / \mathrm{L}$, the numerical value is the same as for concentrations in parts per million.

Specific electrical conductance of water is expressed in microsiemens per centimeter at 25 degrees Celsius $(\mu \mathrm{S} / \mathrm{cm})$. This unit is equivalent to micromhos per centimeter at 25 degrees Celsius $(\mu \mathrm{mho} / \mathrm{cm})$, formerly used by the U.S. Geological Survey.

Radioactivity is expressed in picocuries per liter $(\mathrm{pCi} / \mathrm{L})$. A picocurie is one-trillionth $\left(1 \times 10^{-12}\right)$ the amount of radioactivity represented by a curie $(\mathrm{Ci})$. A curie is the amount of radioactivity that yields $3.7 \times 10^{10}$ radioactive disintegrations per second. A picocurie yields 2.22 disintegrations per minute. 


\title{
HYDROLOGY AND WATER QUALITY OF THE FOREST COUNTY
}

\section{POTAWATOMI INDIAN RESERVATION, WISCONSIN}

\author{
By R.A. Lidwin and J.T. Krohelski
}

\section{ABSTRACT}

This report presents data from a study by the U.S. Geological Survey, in cooperation with the Forest County Potawatomi Community of Wisconsin, to document the hydrology and water quality of the Potawatomi Indian Reservation in southern Forest County. Data were collected from October 1981 through September 1987.

Glacial sand and gravel forms the primary aquifer on the reservation. This aquifer is unconfined, and its saturated thickness ranges from approximately 200 feet to zero feet in areas where the bedrock crops out. Horizontal hydraulic conductivity of the glacial deposits is estimated to range from 0.4 to 48 feet per day.

Three watersheds encompass the Reservation: The Wolf, the North Branch Oconto, and the Peshtigo. Estimates of base-flow discharge that will occur on the average once every 2 years for a 7 day period for Reservation streams range from 7.5 $\mathrm{ft}^{3} / \mathrm{s}$ (cubic feet per second) for North Branch Oconto at Wabeno to $32 \mathrm{ft}^{3} / \mathrm{s}$ for the Rat River near Wabeno.

Ground water in the study area is a calcium magnesium bicarbonate type and is suitable for most uses. The ground water sampled during the study was slightly alkaline and moderately hard to very hard; median hardness was $135 \mathrm{mg} / \mathrm{L}$ (milligrams per liter) as calcium carbonate. Alkalinity of ground water ranged from 79 to $318 \mathrm{mg} / \mathrm{L}$; median alkalinity was $123 \mathrm{mg} / \mathrm{L}$ as calcium carbonate.

With the exception of nitrate in water from one well sampled, constituent concentrations were less than the U.S. Environmental Protection Agency's Maximum Contaminant Levels (MCL's) for drinking water. Nitrate plus nitrite concentration was 15 $\mathrm{mg} / \mathrm{L}$ as $\mathrm{N}$, or 50 percent greater than the $\mathrm{MCL}$, in one well located one-half mile northeast of Lake Lucerne.

Secondary Maximum Contaminant Levels (SMCL's) for iron were exceeded in water from two wells. In one of these two well waters, the manganese concentration equaled the SMCL.

Streams on the Reservation also contain a calcium magnesium bicarbonate type water. The stream waters are slightly alkaline and are considered soft to moderately hard; median hardness in stream samples was $56 \mathrm{mg} / \mathrm{L}$ as calcium carbonate. The alkalinity in stream samples ranged from 46 to $59 \mathrm{mg} / \mathrm{L}$ as calcium carbonate; the median value was $51 \mathrm{mg} / \mathrm{L}$. Stream water is intermediate between hard, alkaline ground water and soft, acidic precipitation and surface runoff. Low but detectable concentrations of chromium, copper, iron, magnesium, mercury, and zinc were detected in most bottom-material samples.

Water quality of three lakes on the Reservation is variable and depends on the degree of connection with the ground-water system. In general, Bug Lake and Devils Lake are in poor hydraulic connection with the ground-water system, and their waters contain low concentrations of dissolved solids and alkalinity and low $\mathrm{pH}$. King Lake is in good hydraulic connection with the ground-water system, and its waters contain higher concentrations of dissolved solids and alkalinity and higher $\mathrm{pH}$ than Bug and Devils Lakes.

\section{INTRODUCTION}

The Forest County Potawatomi Community of Wisconsin is concerned about the potential effects of proposed large-scale mining near the Potawatomi Indian Reservation. To address these concerns, the U.S. Geological Survey (USGS), in cooperation with the Community, conducted a 
hydrologic study of the Reservation. The objectives of the study were to characterize the ground-water hydrology and surface- and ground-water quality within the Potawatomi Indian Reservation.

\section{Purpose and Scope}

This report summarizes selected ground-water and surface-water data collected during the study. The report is not intended to be a comprehensive description of water resources of the Reservation, but rather it presents baseline water data for use by tribal planners and others in future site-specific investigations and studies concerned with long-term water-quality trends in the Reservation area.

Some data have been analyzed and interpreted; other data are presented in tabular form with minimal discussion. Data from test holes, seismic-refraction survey lines, and sampled and measured wells were used to compile water-table, saturated thickness, and bedrock-altitude maps. In situ displacement-recovery tests of nine observation wells were analyzed to estimate the hydraulic properties of the sand and gravel aquifer. Water samples from 22 wells, 4 streams, and 3 lakes were analyzed to describe chemical characteristics of water throughout the Reservation. The results of these analyses were interpreted and are also presented in tabular form.

\section{Physical Setting}

The Potawatomi Indian Reservation consists of noncontiguous parcels of land in southern Forest County, Wis. The total area of the Reservation, which includes tribally owned and allotted land, is 11,667 acres (Wisconsin Legislative Reference Bureau, 1986). Because the Reservation consists of noncontiguous parcels of land, a study area larger than the Reservation was adopted for this investigation. The study area and the location of Reservation lands within the study area are shown on plate 1 .

The study area lies within the Northern Highland geographical province (Martin, 1965). The Northern Highland Province includes roughly the northern one-third of Wisconsin. Maximum elevation is $1,700 \mathrm{ft}$ above sea level. Local topographic relief in the study area is about $200 \mathrm{ft}$. Approximately 80 to 85 percent of the Reservation area is forested with second-growth hardwoods. The remainder consist of wetlands and agricultural fields.

The geology of the study area consists of Precambrian crystalline bedrock and overlying glacial sediment. The Precambrian bedrock is part of the Canadian Shield and consists of a wide variety of igneous and metamorphic rocks (Greenberg and Brown, 1984). The bedrock surface gently slopes to the southeast over much of the study area (pl. 2); however, because of significant bedrock relief (as much as $360 \mathrm{ft}$ ) bedrock crops out in the southern and southeastern parts of the study area.

Glacial sediment is a result of deposition associated with the Langlade lobe of the Laurentide Ice Sheet. Glacial ice flowed from the northeast to the southwest as indicated by the long axis of drumlins (low rounded hills), which consist primarily of sand and gravel mantled by till. Two drumlins, one north of Lake Lucerne trending to the south and one in the south-central part of the study area trending to the southwest, are especially large (Simpkins and others, 1987). Landforms consisting of sand and gravel are associated with drumlins. Ice-contact features, such as kame terraces, generally abut drumlins and are always intermediate in altitude between the drumlins and outwash in valleys. Ice-contact features and outwash are comprised of high permeable sand and gravel, which form the local sand and gravel aquifer. Permeability of till is typically low (Freeze and Cherry, 1979, p. 29). Thickness of the glacial sediment varies from zero in bedrock-outcrop areas to approximately $340 \mathrm{ft}$ west of Lake Lucerne.

\section{Site-Identification Systems}

Each stream station, lake site, and groundwater site mentioned in this report is assigned a unique identification number. The systems used by the USGS to assign identification numbers for stream sites and for lake and ground-water well sites differ, but both systems are based on geographic location.

An eight-digit "downstream-order number" is used for sites on streams. The first two digits denote the main drainage basin ("04" is assigned to the Lake Michigan Basin); the last six digits, which increase in downstream order, are unique to a specific site. 
Lake and ground-water sites are identified by a unique 15-digit number that is a concatenation of the site's latitude and longitude and a two-digit sequence number. The sequence number is used to distinguish between sites with the same latitudelongitude designation. Each ground-water site is also identified by a local number based on the cadastral-survey system of the U.S. Government. The number consists of an abbreviation of the county name; the township, range and section; and a four-digit number assigned to the well. For example, site FR-34/15E/28-0579 is in Forest County (FR), township 34 north, range 15 east, section 28; its sequence number is 579 . On plate 1 , only the sequence number is used to identify ground-water sites.

\section{Acknowledgments}

The authors thank J.R. Holms, Mining Impact Coordinator of the Potawatomi Indian Reservation, for his help and information; Charles A. McCuddy, U.S. Bureau of Indian Affairs, for his help in activity coordination; and members of the Forest County Potawatomi Community for their interest and cooperation.

\section{HYDROLOGY}

The results and interpretation of data collected to describe ground- and surface-water hydrology are discussed below. Results of all analyses and measurements are listed in appendixes $A$ and $B$.

\section{Ground Water}

Ground water is the source of all domestic water used in the southern Forest County area. Because the Precambrian bedrock yields only small quantities of ground water, most of the ground water is withdrawn from the sand and gravel aquifer in the study area. The aquifer lacks laterally extensive layers of poorly permeable material. As a result, the aquifer is unconfined, or under watertable conditions, throughout the study area.

The ground-water hydrology of the Reservation was investigated by means of several approaches. Water levels were measured, geologic data on 58 wells were analyzed (appendix A), and 9 seismic-refraction surveys (pl. 1) were used to define the water table and the saturated thickness of the sand and gravel aquifer. In addition, in situ displacement-recovery testing was done to estimate the horizontal hydraulic conductivity of the sand and gravel aquifer.

\section{Water-Table Configuration and Saturated Thickness}

The configuration of the water table in the study area is shown on plate 3. Generally, the configuration of the water table is similar to surface topography but somewhat subdued. The water table most closely resembles surface topography in areas of low permeability (areas mantled by till) because infiltrating recharge cannot dissipate as quickly as in areas of high permeability (areas mantled by sand and gravel). Within the areas of low permeability, closely spaced contours indicate a steep horizontal gradient in the water-table system (pl. 3). In contrast, widely spaced contours in areas of higher permeability indicate a slight horizontal gradient within the water-table system.

The water table is at or near the surface in the vicinity of some lakes and wetlands. In other parts of the study area, depth to the water table can be as great as $165 \mathrm{ft}$. Generally, ground water flows from topographic high areas to topographic low areas, where it discharges to streams, lakes, and wetlands. Generalized horizontal ground-water flow in the study area is shown on plate 3 .

Areal differences in saturated thickness of the glacial sediment is shown on plate 4. Saturated thickness was calculated by subtracting bedrocksurface altitudes from associated water-table altitudes. Although saturated thickness ranges from zero (at bedrock outcrops) to approximately $200 \mathrm{ft}$ in the study area, a $60-$ to 160 -ft range predominates in and around the Reservation. Generally, areas of greatest saturated thickness of permeable materials are the best suited for water supply.

\section{Aquifer Properties and Ground-Water Flow}

Aquifers transmit water from recharge areas to discharge areas. The factors that affect the quantity of ground water transmitted are expressed in Darcy's Law:

$$
Q=K \times A \times d h / d l
$$

where

$Q$ is the quantity of ground water per unit time, 
$\mathrm{K}$ is the hydraulic conductivity of the aquifer,

$A$ is the cross-sectional area

(perpendicular to flow), and

$\mathrm{dh} / \mathrm{dl}$ is the hydraulic gradient.

Hydraulic conductivity indicates the ability of an aquifer to transmit water. In this report, hydraulic conductivity is expressed in terms of feet per day $(\mathrm{ft} / \mathrm{d})^{1}$. A displacement-recovery test, or "slug" test, was used during this study to calculate horizontal hydraulic conductivity. In this test, a known quantity of water (or "slug") in a well is displaced, and subsequent recovery of the water level as a function of time is monitored (Bouwer and Rice, 1976). The local horizontal hydraulic conductivity in the immediate vicinity of the well can be calculated from the rate of recovery.

The horizontal hydraulic conductivities estimated during this study range from 0.4 to $48 \mathrm{ft} / \mathrm{d}$; the geometric mean is $4.6 \mathrm{ft} / \mathrm{d}$ (appendix $\mathrm{B}$ ). This variation is likely a result of the inhomogeneity of the sand and gravel aquifer at the local scale of the displacement-recovery tests. These hydraulic conductivities, however, are within the ranges for silty sand, till, and clean fine sand given by Freeze and Cherry (1979, p. 29).

The crystalline Precambrian bedrock is not a significant source of ground water in the study area. The hydraulic conductivity of the bedrock is largely dependent on the presence or absence of fractures within the bedrock. Although the amount of fracturing of the bedrock in the site area is not known, data collected by Dames and Moore (written commun., 1979) indicate that fracturing is not extensive and that hydraulic conductivities in bedrock are much lower than those in the sand and gravel aquifer. Estimated hydraulic conductivity of the bedrock ranges from 0.0003 to $0.03 \mathrm{ft} / \mathrm{d}$.

Horizontal hydraulic gradients define the slope of the water table. Specifically, the slope is the change in water level divided by the horizontal distance. The water-table map (pl. 3) indicates that horizontal hydraulic gradients of a till unit and the sand and gravel aquifer are typically $0.019 \mathrm{ft} / \mathrm{ft}$ and $0.0075 \mathrm{ft} / \mathrm{ft}$, respectively.

The rate of contaminant movement in aquifers is commonly approximated by calculating groundwater velocity, even though estimates of groundwater velocity do not account for contaminant- transport processes such as contaminant adsorption, decay, or dispersion (Freeze and Cherry, 1979, p. 75). Ground-water velocities are estimated by use of the following modified form of Darcy's Law:

where

$$
\mathrm{v}=\mathrm{K} / \mathrm{n} \times \mathrm{dh} / \mathrm{dl}
$$

$\mathrm{v}$ is the ground-water velocity,

$\mathrm{K}$ is the hydraulic conductivity of the aquifer,

$\mathrm{n}$ is the porosity of the aquifer, and $\mathrm{dh} / \mathrm{dl}$ is the hydraulic gradient.

The porosity of an aquifer is defined as the volume of void space in the aquifer divided by the total volume of the aquifer. Porosities commonly range from 40 to 70 percent, 25 to 50 percent, and 25 to 40 percent in clay, sand, and gravel, respectively (Freeze and Cherry, 1979, p. 37). If ground water is to move freely through an aquifer, however, the aquifer must be somewhat permeable. For example, porosities of clay deposits are high, but permeabilities are low. Thus, the water within clay deposits is not economically obtainable.

Two estimates of ground-water velocity were calculated for the sand and gravel aquifer by use of equation 2. Given a horizontal hydraulic conductivity of $48 \mathrm{ft} / \mathrm{d}$ (the highest estimated value from the slug tests), an average porosity of 25 percent, and an average horizontal hydraulic gradient of 0.0075 $\mathrm{ft} / \mathrm{ft}$, ground-water velocity is about $1.4 \mathrm{ft} / \mathrm{d}$. Given a horizontal hydraulic conductivity of $0.4 \mathrm{ft} / \mathrm{d}$ (the lowest estimated value from slug tests), an average porosity of 35 percent and an average horizontal hydraulic gradient of $0.019 \mathrm{ft} / \mathrm{ft}$, ground-water velocity is about $0.02 \mathrm{ft} / \mathrm{d}$. It should be noted that stresses imposed on the ground-water system, such as pumping, can affect one or more of the variables used in these calculations, and groundwater velocities could differ from those reported here.

\section{Surface Water}

Forest County is part of the Lake Michigan drainage basin. Intermediate river basins encompassing the study area include the Fox-Wolf and the Menominee-Oconto-Peshtigo river basins. With-

\footnotetext{
${ }^{1}$ Feet per day is a mathematical reduction of cubic feet per day per square foot $\left[\left(\mathrm{ft}^{3} / \mathrm{d}\right) / \mathrm{ft}^{2}\right]$.
} 
in these basins, the Wolf, the North Branch Oconto, and the Peshtigo are the three primary river systems that drain the Reservation (pl. 1).

Important sources of streamflow include precipitation that falls directly into streams, precipitation or snowmelt that flows overland into streams as direct runoff, and base flow. Base flow, which is derived largely from the discharge of ground water from aquifer systems to surface-water systems, is a major component of streamflow in the study area. Ground-water discharge can account for all streamflow during drought periods when there is no precipitation or during the winter when precipitation falls in the form of snow and surface-soil layers are frozen, limiting recharge to the underlying aquifer.

Base flow is commonly expressed by the value $Q_{7,2}$ or $Q_{7,10}$. For example, $Q_{7,2}$ is the baseflow discharge in cubic feet per second $\left(\mathrm{ft}^{3} / \mathrm{s}\right)$ that will occur on the average once every 2 years for a 7-day period.

Base flow for streams that do not have gaging stations can be estimated using equations and methods developed by Holmstrom (1980).

Base-flow discharges for four sites on streams near stream-water quality sites are as follows: an intermittent outlet; Devils Lake and King Lake are classified as lakes without any inlet or outlet.

Lakes differ in degree of hydraulic connection to the surrounding ground-water system. It is difficult to assess the degree of such interaction through investigation of the physical system alone. Commonly, the degree of interconnection can be estimated only by examination of ground-water and lake-water chemistries. Results of analyses of samples from all three lakes and the ground-water system and a discussion of lake/ground-water interaction are presented in the next section.

\section{WATER QUALITY}

The results of analyses of water samples collected from ground-water and surface-water systems in the study area are discussed below. All water samples were collected in accordance with USGS standard practice (U.S. Department of the Interior, 1977) and were analyzed at the USGS National Water-Quality Laboratory in Denver, Colo. Specific conductance, temperature, and $\mathrm{pH}$ were measured in the field at the time of sample collection. Results of all analyses and measurements are listed in appendixes $\mathrm{C}-\mathrm{H}$.

\begin{tabular}{lllcc}
$\begin{array}{c}\text { Station } \\
\text { number }\end{array}$ & \multicolumn{1}{c}{ Station name } & $\begin{array}{c}\text { area } \\
\left(\mathrm{mi}^{2}\right)\end{array}$ & $\begin{array}{c}\mathrm{Q}_{7,2} \\
\left(\mathrm{ft}^{3} / \mathrm{s}\right)\end{array}$ & $\begin{array}{c}\mathrm{Q}_{7,10} \\
\left(\mathrm{ft}^{3} / \mathrm{s}\right)\end{array}$ \\
\hline 04067900 & Rat River near Wabeno & 82.1 & 32 & 20 \\
04067950 & Otter Creek near Lakewood & 32.1 & 18 & 13 \\
04069690 & North Branch Oconto at Wabeno & 31.3 & 7.5 & 4.5 \\
04069800 & North Branch Oconto near Carter & 58.2 & 17 & 12 \\
\hline
\end{tabular}

The locations of these stations are shown on plate 1 except for Otter Creek near Lakewood, which is just east of the map border.

Lakes can be divided into three hydrologic types: (1) Lakes with at least one inlet and one outlet, (2) lakes with only an outlet, and (3) lakes without any inlet or outlet (Novitzki and Devaul, 1978). Lakes investigated in the study area were Bug Lake, Devils Lake, and King Lake. Bug Lake is classified as a lake without an inlet but with

\section{Ground Water}

Ground-water samples were collected from 17 domestic wells and from 5 observation wells installed by the USGS. Concentrations of major cations and anions in water from these 22 wells were determined to characterize the ground-water chemistry in the study area. In addition, nitrogen and trace-metal analyses were done on selected samples to identify possible areas of ground-water contamination. 
Analytical results for ground-water samples from the sand and gravel aquifer are summarized in table 1. A modified Stiff diagram showing average major-ion concentrations (fig. 1) indicates that the predominant ground-water type is calcium magnesium bicarbonate. This water type, which is a result of dissolution of carbonate minerals, is the most prevalent water type in Wisconsin's ground water (Kammerer, 1984, p. 12, 20, 28, and 36).

\section{pH, Alkalinity, and Hardness}

The $\mathrm{pH}$ of ground-water samples collected in the study area ranged from 7.3 to 9.3 , and the median $\mathrm{pH}$ was 8.1. Values of $\mathrm{pH}$ in this range are considered moderately basic.

Alkalinity of samples from the study area ranged from 79 to $318 \mathrm{mg} / \mathrm{L}$ as calcium carbonate, and the median was $123 \mathrm{mg} / \mathrm{L}$ as calcium carbonate. Kammerer $(1981$, p. 14$)$ reported that typical alkalinities in Forest County ranged from 12 to 155 $\mathrm{mg} / \mathrm{L}$ as calcium carbonate. The higher alkalinities measured during this study are thought to be a result of different aquifer mineralogy. Most of the 93 samples studied by Kammerer (1981, p. 14) were from the Mole Lake area; however, it is likely that the sand and gravel aquifer in the study area contains more carbonate material (limestone and dolomite) than it does in the Mole Lake area. Therefore, more carbonate is available for dissolution, and alkalinity concentrations are correspondingly higher.

The water-hardness classification of Durfor and Becker (1964) is used in this report:

\begin{tabular}{cc}
$\begin{array}{c}\text { Hardness range } \\
\left(\mathrm{mg} / \mathrm{L} \text { as } \mathrm{CaCO}_{3}\right)\end{array}$ & Hardness description \\
\hline $0-60$ & Soft \\
$61-120$ & Moderately hard \\
$121-180$ & Hard \\
Greater than 180 & Very hard
\end{tabular}

The hardness of water samples from wells on the Reservation ranged from 79 to $490 \mathrm{mg} / \mathrm{L}$ as calcium carbonate, and the median hardness was $135 \mathrm{mg} / \mathrm{L}$ as calcium carbonate. Thus, ground water on the Reservation is considered moderately hard to very hard.

Table 1. Summary of physical and chemical characteristics of water from wells on the Potawatomi Indian Reservation, 1982-83

[Units are milligrams per liter unless otherwise indicated. $\mu \mathrm{S} / \mathrm{cm}$, microsiemens per centimeter at 25 degrees Celsius; < , less than]

\begin{tabular}{lcccc}
\hline \multicolumn{1}{c}{ Characteristic } & $\begin{array}{c}\text { Number } \\
\text { of wells }\end{array}$ & Minimum & Maximum & Median \\
\hline Specific conductance $(\mu \mathrm{S} / \mathrm{cm})$ & 22 & 155 & 660 & 250 \\
$\mathrm{pH}$ (units) & 22 & 7.3 & 9.3 & 8.1 \\
Hardness, as $\mathrm{CaCO}_{3}$ & 21 & 79 & 490 & 135 \\
Calcium, dissolved & 21 & 20 & 110 & 30 \\
Magnesium, dissolved & 21 & 5.3 & 53 & 14 \\
Sodium, dissolved & 21 & 1.2 & 26 & 2.8 \\
Potassium, dissolved & 21 & .4 & 3.7 & .9 \\
& & & & 123 \\
Alkalinity, as CaCO & 21 & 79 & 18 & 9.0 \\
Sulfate, dissolved & 21 & 2.0 & 78 & 2.6 \\
Chloride, dissolved & 21 & .6 & .80 & .10 \\
Fluoride, dissolved & 9 & $<.10$ & 17 & 14 \\
Silica, dissolved & 20 & 2.4 & 595 & 149 \\
Dissolved solids, residue & 21 & 107 & & .29 \\
$\quad$ at 180 degrees Celsius & 17 & $<.10$ & & \\
Nitrate plus nitrite, & & & & \\
$\quad$ as N, dissolved & & & & \\
\hline
\end{tabular}




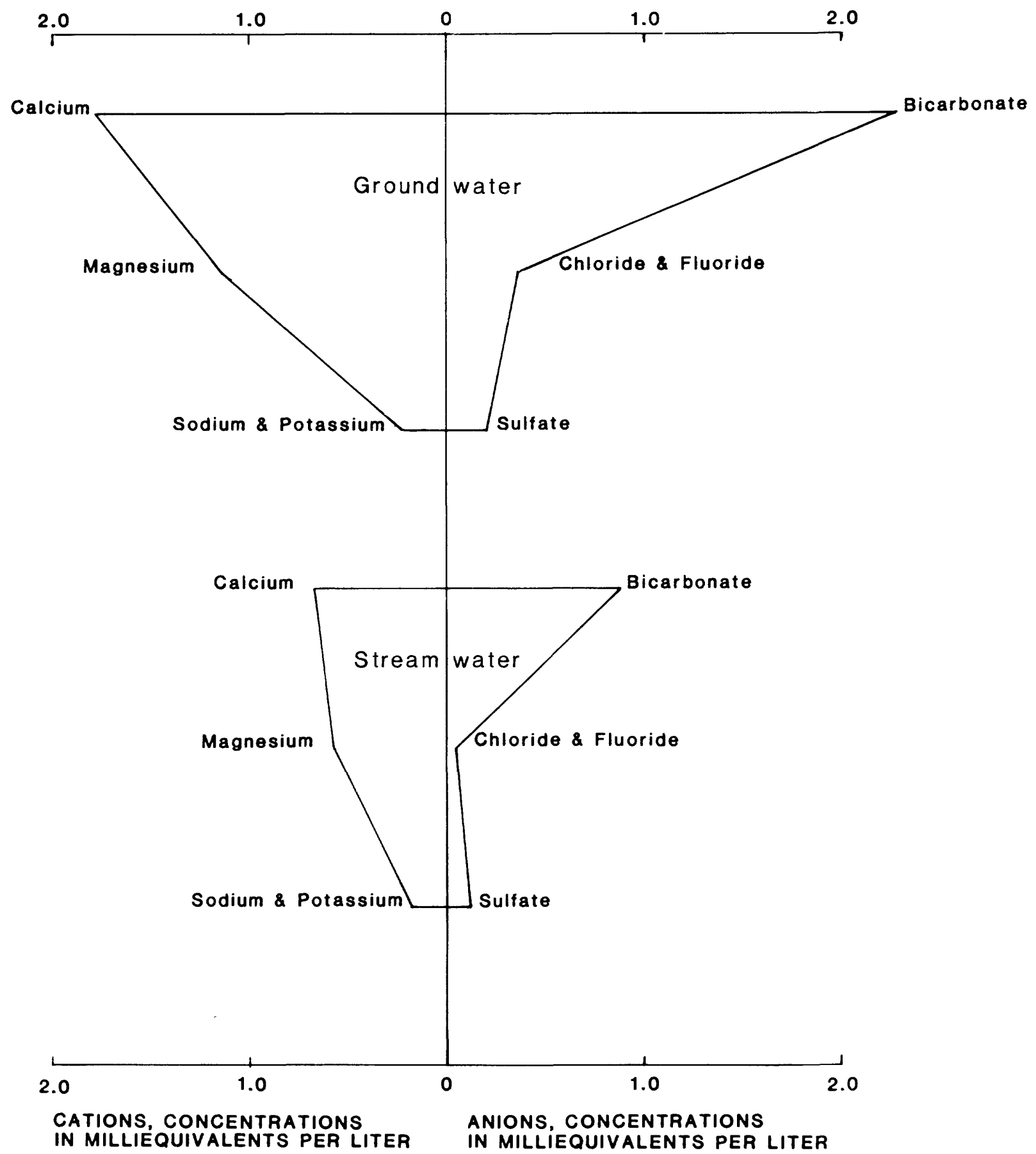

Figure 1. Modified stiff diagram showing major-ion concentrations of ground water and stream water of the Potawatomi Reservation. 


\section{Concentrations of Selected Constituents}

Results of fluoride, nitrate-plus-nitrite, and metals analyses are summarized in tables 1 and 2 . For comparison, the U.S. Environmental Protection Agency (USEPA) maximum contaminant levels (MCL's) and secondary maximum contaminant levels (SMCL's) for selected constituents and properties are shown in table 3. The USEPA levels are used to assess the suitability of ground water for use as drinking water.

With the exception of one well about one-half mile northeast of Lake Lucerne, no wells sampled in this study yielded water in which ion concentrations exceeded the MCL's listed in table 3 . The sample from the well near Lake Lucerne contained $15 \mathrm{mg} / \mathrm{L}$ of nitrate as nitrogen--a concentration 50 percent higher than the $\mathrm{MCL}$ of $10 \mathrm{mg} / \mathrm{L}$ as $\mathrm{N}$. Because elevated nitrate concentrations in ground water may indicate contamination from septic drainfields or animal wastes, the well was resampled for fecal coliform bacteria (an indicator of fecal contamination). No fecal coliform bacteria were found in the sample.

Iron concentrations in water from two wells exceeded the USEPA'S SMCL. One of these well waters also contained manganese concentration that equaled the SMCL. Although iron and manganese do not pose health risks, high concentrations of these constituents can result in objectional taste and staining of fixtures and laundry.

\section{Radiochemical Activity}

Radiochemical analyses were also done on samples collected from the study area. Concentrations of radionuclides can be expressed either in terms of activities of specific radionuclides (radon or radium) or as a gross activity of specific radioactive particles (commonly alpha or beta particles).

Total gross alpha particle activity ranged from $<3.1$ to $<9.2 \mathrm{pCi} / L$ as uranium in samples collected from 14 wells during this study. Presently, the USEPA has established an MCL of $15 \mathrm{pCi} / \mathrm{L}$ for gross alpha-particle activity in drinking water (U.S. Environmental Protection Agency, 1990). Radon activity ranged from 89 to $2,510 \mathrm{pCi} / \mathrm{L}$, and the median radon activity in water from seven wells sampled during this study was $391 \mathrm{pCi} / \mathrm{L}$ (appendix $E)$. An MCL for the activity of radon in water has not been promulgated at this time.

\section{Surface Water}

Surface-water samples were collected from four streams (at five sites) and from three lakes on the Reservation. Results of major cation and anion analyses were used to characterize the surfacewater chemistry. In addition, bottom materials collected from four streams were analyzed for trace elements, and water samples collected from the three lakes were analyzed for metal ions. Results of all analyses are listed in appendixes F-H. Results of the stream-water analyses are summarized in figure 1 and in tables 4 and 5 .

\section{Streams}

The shape of the surface-water Stiff diagram in figure 1 is similar to that of the ground-water Stiff diagram. The similarity indicates that surface water also is of the calcium magnesium bicarbonate type. The concentrations of the major constituents in the surface water, however, are less than the corresponding concentrations in the ground water. This is likely due to dilution of the ground-water runoff component of streamflow by precipitation and surface runoff.

\section{$\mathrm{pH}$, Alkalinity and Hardness}

The $\mathrm{pH}$ of the streams sampled ranged from 7.2 to 8.0 , and the median $\mathrm{pH}$ was 7.4 . The $\mathrm{pH}$ values of streams measured during this study are within the range of values reported by Hem (1985, p. 64) for surface waters not affected by contamination. It should be noted that these values are lower than those for ground water sampled in this study. This difference may be a result of microbiological factors or a result of the mixing of acidic precipitation and ground water.

Alkalinity measured in the stream samples from the study area ranged from 46 to $59 \mathrm{mg} / \mathrm{L}$ as calcium carbonate, and the median was $51 \mathrm{mg} / \mathrm{L}$ as calcium carbonate. As with $\mathrm{pH}$, alkalinity of stream water was lower than that for ground water because the mixing of precipitation and ground water.

The mixing of ground water with dilute precipitation will also reduce the calcium and magnesium concentration, thus reducing hardness. Hardness in stream samples collected during this study ranged from 50 to $63 \mathrm{mg} / \mathrm{L}$ as calcium carbonate, and the median was $56 \mathrm{mg} / \mathrm{L}$ as calcium carbonate. 
Table 2. Summary of trace-constituent analyses of water from wells on the Potawatomi Indian Reservation, 1982-83

[All sample analyses are for dissolved constituents; units are micrograms per liter; <, less than]

\begin{tabular}{|c|c|c|c|c|}
\hline \multirow[b]{2}{*}{ Constituent } & \multirow{2}{*}{$\begin{array}{l}\text { Number } \\
\text { of wells }\end{array}$} & \multicolumn{3}{|c|}{ Concentration of constituent } \\
\hline & & Minimum & Maximum & Median \\
\hline Arsenic & 5 & 1 & 4 & 3 \\
\hline Barium & 4 & 15 & 46 & 29 \\
\hline Cadmium & 4 & $<1$ & 4 & 2 \\
\hline Chromium & 4 & 10 & 20 & 10 \\
\hline Copper & 4 & $<10$ & 30 & $<10$ \\
\hline Iron & 4 & $<3$ & 6,500 & 305 \\
\hline Lead & 4 & $<10$ & 10 & $<10$ \\
\hline Manganese & 4 & 11 & 380 & 120 \\
\hline Mercury & 5 & $<.1$ & $<.1$ & $<.1$ \\
\hline Selenium & 4 & $<1$ & $<1$ & $<1$ \\
\hline Silver & 5 & $<1.0$ & $<1.0$ & $<1.0$ \\
\hline Zinc & 5 & 35 & 230 & 100 \\
\hline
\end{tabular}

Table 3. Summary of selected U.S. Environmental Protection Agency drinking-water regulations

[From U.S. Environmental Protection Agency, 1990. All units are milligrams per liter unless otherwise specified. Dashes (--) indicate not applicable.]

\begin{tabular}{lcc}
\hline Constituent or property & $\begin{array}{c}\text { Maximum } \\
\text { contaminant level }\end{array}$ & $\begin{array}{c}\text { Secondary maximum } \\
\text { contaminant level }\end{array}$ \\
\hline Arsenic & 0.050 & -- \\
Barium & 1.0 & -- \\
Cadmium & -010 & -- \\
Chromium & .050 & -- \\
Lead & -050 & -- \\
Mercury & .002 & -- \\
Selenium & -010 & -- \\
Silver & -050 & -- \\
Fluoride & 4.0 & -- \\
Nitrate (as nitrogen) & 10 & -- \\
Radionuclides, gross alpha & 15 & -- \\
particle activity & & \\
(picocuries per liter) & & 250 \\
Chloride & -- & 1 \\
Copper & -- & .3 \\
Iron & -- & .05 \\
Manganese & -- & $6.5-8.5$ \\
pH (units) & -- & 250 \\
Sulfate & -- & 500 \\
Total dissolved solids & -- & 5 \\
Zinc & -- & \\
\hline & & \\
\hline
\end{tabular}


Table 4. Summary of physical and chemical characteristics of water from streams on the Potawatomi Indian Reservation, 1982-83

[Units are milligrams per liter unless otherwise indicated; values are based on five samples at base flow; $\mu \mathrm{S} / \mathrm{cm}$, microsiemens per centimeter at 25 degrees Celsius; <, less than]

\begin{tabular}{lccc}
\hline \multicolumn{1}{c}{ Characteristic } & Minimum & Maximum & Median \\
\hline & & & \\
Specific conductance $(\mu \mathrm{S} / \mathrm{cm})$ & 95 & 715 & 110 \\
$\mathrm{pH}$ (units) & 7.2 & 7.6 & 7.4 \\
Hardness, total as $\mathrm{CaCO}_{3}$ & 50 & 15 & 56 \\
Calcium, dissolved & 12 & 6.3 & 13 \\
Magnesium, dissolved & 4.9 & 1.8 & 5.6 \\
& & 1.0 & 1.3 \\
Sodium, dissolved & 1.1 & 59 & .8 \\
Potassium, dissolved & .5 & 11 & 10 \\
Alkalinity, as CaCO & 46 & 2.0 & 1.1 \\
Sulfate, dissolved & 6.0 & & \\
Chloride, dissolved & 1.0 & .10 & $<.10$ \\
& & 6.1 & 4.9 \\
Fluoride, dissolved & $<.10$ & 108 & 94 \\
Silica, dissolved & 4.1 & & \\
Dissolved solids, residue & 77 & & \\
$\quad$ at 180 degrees Celsius & & & \\
\end{tabular}

Table 5. Summary of trace-element analyses of bottom material from streams on the Potawatomi Indian Reservation, 1982-83

[Units are micrograms per gram; <, less than]

\begin{tabular}{lccc}
\hline Constituent & Minimum & Maximum & Median \\
\hline Arsenic & $<1$ & $<1$ & $<1$ \\
Cadmium & $<1$ & $<1$ & $<1$ \\
Chromium & 3 & 6 & 4 \\
Copper & 2 & 5 & 4 \\
Iron & 690 & 4,700 & 1,100 \\
& & & $<$ \\
Lead & $<10$ & $<10$ & $<6$ \\
Manganese & 29 & 630 & .01 \\
Mercury & $<.01$ & .01 & $<10$ \\
Nickel & $<10$ & $<10$ & 8 \\
Zinc & 6 & 30 & \multicolumn{2}{c}{} \\
\end{tabular}


The median hardness is less than half of that for ground water, and it would be described as soft to moderately hard on the basis of the classification of Durfor and Becker (1964).

\section{Concentrations of Selected Constituents}

Concentrations of selected trace elements in bottom materials were determined for four streams at five sites. Results of the bottom-material analyses are summarized in table 4. Chromium, copper, iron, manganese, mercury, and zinc were detected in the samples. Although there are no regulations regarding the maximum allowable metal concentration in sediments, it is thought that these bottommaterial concentrations correspond to much lower dissolved and (or) suspended concentrations in stream water that do not pose a threat to the aquatic plant and animal communities in the study area.

\section{Lakes}

Water samples from three lakes on the Reservation were analyzed for major cations and anions to help delineate the degree of surface-water/ ground-water interaction. These data are also important in characterizing the lake-water type and providing a baseline for monitoring any future changes to lake-water chemistry. Lake-water samples were also analyzed for metals (appendix H).

On the basis of the analytical data, Bug Lake and Devils Lake are thought to be in poor hydraulic connection with the surrounding ground-water system. This poor connection is evidenced by low $\mathrm{pH}$ and low concentrations of alkalinity and dissolved solids. These lakes apparently receive most of their water from direct precipitation and surface runoff. In addition, Devils Lake is bordered by a bog area typical of hydrologic settings where ground water is not a significant source of water (Mitsch and Gosselink, 1986, p. 301).

King Lake is thought to be in good hydraulic connection with the surrounding ground-water system, as evidenced by its much higher $\mathrm{pH}$ and concentration of alkalinity and much higher concentration of dissolved solids.

Results of analyses indicate nondetectable or otherwise low concentrations of metals in water from all three lakes.

\section{SUMMARY}

The study area in southern Forest County, Wis., includes the dispersed parcels of land that comprise the Potawatomi Indian Reservation. The area consists of unconsolidated glacial material overlying largely impermeable Precambrian crystalline bedrock. The unconsolidated sediments are as much as $340 \mathrm{ft}$ thick, but they are absent in areas where bedrock crops out at the surface.

Most water used for domestic purposes in the study area is ground water. Because the Precambrian bedrock is not a significant source of ground water, glacial sand and gravel forms the primary aquifer on the Reservation. The aquifer is unconfined, and its saturated thickness ranges from approximately $200 \mathrm{ft}$ (in areas where the glacial deposits are relatively thick) to zero feet (in areas where the bedrock crops out). A range of 60 to 160 $\mathrm{ft}$ of saturated thickness is common in and around the Reservation. Horizontal hydraulic conductivity of the sand and gravel deposits was analyzed by means of in situ displacement-recovery (slug) tests. The estimated horizontal hydraulic conductivity ranges from 0.4 to $48 \mathrm{ft} / \mathrm{d}$; the geometric mean is $4.6 \mathrm{ft} / \mathrm{d}$. Because ground-water withdrawals from till in the study area are not economically feasible, the hydraulic conductivity of the till was not investigated.

The horizontal hydraulic gradient, or slope, of the water table ranges from $0.0075 \mathrm{ft} / \mathrm{ft}$ in the sand and gravel areas of the study site to $0.019 \mathrm{ft} / \mathrm{ft}$ in the till areas. Estimates of ground-water velocities within the glacial deposits are about $1.4 \mathrm{ft} / \mathrm{d}$ in the sand and gravel deposits and about $0.02 \mathrm{ft} / \mathrm{d}$ in the tills.

Reservation lands lie within three surfacewater basins: the Wolf, the North Branch Oconto, and the Peshtigo. Estimates of base-flow discharge that will occur on the average once every 2 years for a 7-day period for Reservation streams range from $7.5 \mathrm{ft}^{3} / \mathrm{s}$ for the North Branch Oconto at Wabeno to $32 \mathrm{ft}^{3} / \mathrm{s}$ for the Rat River near Wabeno.

The ground water in the study area is a calcium magnesium bicarbonate type. This ion assemblage is the most common water type in Wisconsin. The ground water sampled during the study was moderately hard to very hard and slightly alkaline; median hardness was 135 milligrams per liter as 
calcium carbonate. Alkalinity ranged from 79 to 318 $\mathrm{mg} / \mathrm{L}$; median alkalinity was $123 \mathrm{mg} / \mathrm{L}$ as calcium carbonate.

Concentrations of selected constituents in ground water, with the exception of nitrate at one well sampled, were less than USEPA MCL's for drinking water. At that one well, the nitrate plus nitrite concentration of $15 \mathrm{mg} / \mathrm{L}$ as $N$ exceeded the $\mathrm{MCL}$ of $10 \mathrm{mg} / \mathrm{L}$ as N. Gross alpha-particle activity, a byproduct of radioactive decay, ranged from $<3.1$ to $<9.2 \mathrm{pCi} / \mathrm{L}-$ values less than the USEPA MCL of $15 \mathrm{pCi} / \mathrm{L}$. Radon concentrations ranged from 89 to $2,510 \mathrm{pCi} / \mathrm{L}$. The $S M C L$ for iron was exceeded in two wells; in water from one well, the SMCL for manganese was equaled.

Water in streams on the Reservation is also of the calcium magnesium bicarbonate type; this similarity in water type indicates considerable surface-water/ground-water interaction in the study area. Sampled streams contain soft to moderately hard, slightly alkaline water. Median hardness in samples collected during the study was $56 \mathrm{mg} / \mathrm{L}$ as calcium carbonate. Alkalinity in the streams ranged from $46 \mathrm{mg} / \mathrm{L}$ to $59 \mathrm{mg} / \mathrm{L}$, and median alkalinity was $51 \mathrm{mg} / \mathrm{L}$ as calcium carbonate.

Trace-element concentrations in bottom materials of five stream sites were mostly below detection. Some detectable concentrations of chromium, copper, iron, magnesium, mercury, and zinc were found.

Dissolved-solids concentrations in the three lakes studied on the Reservation are variable and depend on the degree of connection with the ground-water system. In general, Bug Lake and Devils Lake are in poor hydraulic connection to the ground-water system; water from these lakes has low concentrations of dissolved solids and alkalinity, and low pH. King Lake, however, is in good hydraulic connection with the ground-water system; water from King Lake contains higher concentrations of dissolved solids and alkalinity, and a higher $\mathrm{pH}$.

\section{REFERENCES}

Bouwer, Herman, and Rice, R.C., 1976, A slug test for determining the hydraulic conductivity of unconfined aquifers with completely or partially penetrating wells: Water Resources Research, v. 12 , no. 3 , p. 423-428.
Durfor, C.N., and Becker, Edith, 1964, Public water supplies of the 100 largest cities in the United States, 1962: U.S. Geological Survey WaterSupply Paper 1812, 364 p.

Freeze, R.A., and Cherry, J.A., 1979, Groundwater: Englewood Cliffs, N.J., Prentice-Hall, 604 p.

Greenberg, J.K., and Brown, B.A., 1984, Bedrock geology of Wisconsin, northeast sheet: Wisconsin Geological and Natural History Survey Map 84-2, scale 1:1,000,000.

Hem, J.D., 1985, Study and interpretation of the chemical characteristics of natural water: U.S. Geological Survey Water-Supply Paper 2254, 263 p.

Holmstrom, B.K., 1980, Low-flow characteristics of streams in the Menominee-Oconto-Peshtigo River basin, Wisconsin: U.S. Geological Survey Water-Resources Investigations OpenFile Report 80-749, 82 p.

Kammerer, P.A., Jr., 1984, An overview of groundwater data in Wisconsin: U.S. Geological Survey Water-Resources Investigations Report 83-4239, $58 \mathrm{p}$.

1981, Ground-water-quality atlas of Wisconsin: Wisconsin Geological and Natural History Survey Information Circular 39, 39 p.

Martin, Lawrence, 1965, The physical geography of Wisconsin (3rd ed.): Wisconsin Geological and Natural History Survey Bulletin 36, 608 p.

Mitsch, W.J., and Gosselink, J.G., 1986, Wetlands: New York, Van Nostrand Reinhold, 539 p.

Novitzki, R.P., and Devaul, R.W., 1978, Wisconsin lake levels-their ups and downs: Wisconsin Geological and Natural History Survey Educational Series 9, $11 \mathrm{p}$.

Simpkins, W.W., McCartney, M.C., and Mickelson, D.M., 1987, Pleistocene geology of Forest County, Wisconsin: Wisconsin Geological and Natural History Survey Information Circular $61,21 \mathrm{p}$.

U.S. Department of Interior, 1977, National handbook of recommended methods for water-data acquisition: U.S. Geological Survey, Office of Water-Data Coordination [various pagination]. 
U.S. Environmental Protection Agency, 1990, Drinking water regulations and health advisories: Washington, D.C., U.S. Environmental Protection Agency, Office of Drinking Water, $9 \mathrm{p}$.
Wisconsin Legislative Reference Bureau, 1986, State of Wisconsin, 1985-1986 Blue Book: Wisconsin Department of Administration, 986 p. 
APPENDIXES 
Appendix A. Water-level and well-construction data for domestic and observation wells in the sand and gravel aquifer

[Data on depth of well and screen length are from well-construction reports.

Wells are domestic unless otherwise indicated. --, no data available]

\begin{tabular}{|c|c|c|c|c|c|}
\hline Local well number & $\begin{array}{c}\text { Water-level } \\
\text { measurement } \\
\text { date }\end{array}$ & $\begin{array}{c}\text { Land-surface } \\
\text { altitude } \\
\text { (feet above } \\
\text { sea level) } \\
\end{array}$ & $\begin{array}{c}\text { Water-level } \\
\text { altitude } \\
\text { (feet above } \\
\text { sea level) }\end{array}$ & $\begin{array}{c}\text { Depth of } \\
\text { well } \\
\text { (feet) }\end{array}$ & $\begin{array}{l}\text { Screen } \\
\text { length } \\
\text { (feet) } \\
\end{array}$ \\
\hline FR-34/15E/28-0579 & -- & 1,570 & -- & 96 & 10 \\
\hline FR-34/15E/28-0580 & -- & 1,510 & -- & 95 & 14 \\
\hline FR-36/13E/35-0582 & -- & 1,875 & -- & 331 & 3 \\
\hline FR-36/13E/35-0586 & $06-08-82$ & 1,800 & 1,642 & 243 & 6 \\
\hline FR-36/13E/36-0592 & -- & 1,770 & -- & 151 & -- \\
\hline FR-36/13E/29-0585 & -- & 1,870 & -- & 253 & 3 \\
\hline${ }^{1}$ FR-36/13E/14-0567 & $11-03-81$ & 1,650 & 1,608 & 63 & 5 \\
\hline FR-36/13E/26-0575 & $06-08-82$ & 1,715 & 1,615 & 118 & -- \\
\hline FR-36/13E/26-0568 & $11-03-81$ & 1,680 & 1,638 & 58 & 10 \\
\hline FR-36/13E/34-0584 & -- & 1,830 & -- & 216 & 3 \\
\hline FR-36/13E/35-0581 & -- & 1,755 & 1,594 & 165 & 4 \\
\hline FR-36/13E/36-0574 & -- & 1,780 & -- & 228 & 6 \\
\hline FR-36/13E/35-0463 & -- & 1,870 & -- & -- & -- \\
\hline FR-35/13E/03-0412 & $06-22-76$ & 1,650 & 1,643 & 30 & - \\
\hline FR-35/13E/03-0413 & $08-07-73$ & 1,665 & 1,648 & 43 & 2 \\
\hline FR-35/13E/02-0569 & -- & 1,710 & -- & 38 & -- \\
\hline FR-35/13E/10-0406 & $08-31-65$ & 1,665 & 1,632 & 75 & 3 \\
\hline FR-35/13E/10-0419 & $06-06-72$ & 1,690 & 1,635 & 70 & -- \\
\hline FR-35/13E/10-0424 & $05-29-69$ & 1,665 & 1,631 & 64 & 3 \\
\hline FR-35/13E/14-0403 & $10-09-74$ & 1,655 & 1,638 & 30 & -- \\
\hline FR-35/14E/17-0439 & $07-25-69$ & 1,675 & 1,610 & 115 & 11 \\
\hline FR-35/14E/03-0434 & $07-20-76$ & 1,620 & 1,570 & 59 & 2 \\
\hline FR-35/14E/02-0066 & $06-21-67$ & 1,620 & 1,609 & 113 & -- \\
\hline FR-35/14E/03-0440 & $09-09-71$ & 1,610 & 1,597 & 77 & -- \\
\hline FR-35/15E/06-0095 & $12-02-67$ & 1,580 & 1,557 & 63 & -- \\
\hline FR-35/15E/05-0429 & $09-04-70$ & 1,570 & 1,544 & 72 & -- \\
\hline FR-35/14E/12-0436 & $10-09-75$ & 1,570 & 1,547 & 55 & -- \\
\hline FR-35/15E/07-0430 & $05-10-73$ & 1,600 & 1,548 & 82 & -- \\
\hline FR-35/14E/14-0435 & $08-27-55$ & 1,630 & 1,605 & 60 & 4 \\
\hline FR-35/15E/18-0431 & $10-09-72$ & 1,580 & 1,545 & 114 & -- \\
\hline FR-35/15E/17-0075 & $01-01-65$ & 1,610 & 1,553 & 100 & 5 \\
\hline FR-35/14E/25-0065 & $12-11-67$ & 1,620 & 1,579 & 141 & 3 \\
\hline${ }^{1}$ FR-35/15E/32-0596 & $11-04-81$ & 1,570 & 1,564 & 21 & 3 \\
\hline FR-34/15E/05-0063 & $11-11-67$ & 1,670 & 1,535 & 241 & -- \\
\hline FR-34/15E/18-0459 & -- & 1,600 & -- & -- & -- \\
\hline
\end{tabular}


Appendix A. Water-level and well-construction data for domestic and observation wells in the sand and gravel aquifer--Continued

\begin{tabular}{|c|c|c|c|c|c|}
\hline Local well number & $\begin{array}{c}\text { Water-level } \\
\text { measurement } \\
\text { date }\end{array}$ & $\begin{array}{c}\text { Land-surface } \\
\text { altitude } \\
\text { (feet above } \\
\text { sea level) }\end{array}$ & $\begin{array}{c}\text { Water-level } \\
\text { altitude } \\
\text { (feet above } \\
\text { sea level) }\end{array}$ & $\begin{array}{c}\text { Depth of } \\
\text { well } \\
\text { (feet) }\end{array}$ & $\begin{array}{l}\text { Screen } \\
\text { length } \\
\text { (feet) }\end{array}$ \\
\hline FR-34/15E/08-0372 & $12-03-64$ & 1,550 & 1,500 & 114 & -- \\
\hline FR-34/15E/16-0578 & -- & 1,555 & -- & 43 & 8 \\
\hline FR-34/15E/28-0589 & -- & 1,560 & 1,500 & 74 & -- \\
\hline FR-34/15E/28-0588 & -- & 1,560 & 1,492 & 110 & - \\
\hline FR-34/15E/33-0074 & $08-15-66$ & 1,580 & 1,490 & 220 & -- \\
\hline FR-34/15E/28-0375 & $03-20-72$ & 1,470 & 1,450 & 46 & 4 \\
\hline FR-35/15E/09-0011 & $06-16-65$ & 1,540 & 1,462 & 124 & 11 \\
\hline FR-35/15E/15-0067 & $06-26-67$ & 1,480 & 1,460 & 56 & -- \\
\hline FR-35/15E/22-0577 & $06-09-82$ & 1,595 & 1,502 & 146 & 3 \\
\hline FR-35/15E/28-0576 & -- & 1,545 & - & 129 & 3 \\
\hline FR-35/15E/23-0565 & $11-03-81$ & 1,480 & 1,471 & 27 & 5 \\
\hline FR-35/15E/36-0566 & $11-03-81$ & 1,430 & 1,421 & 22 & -- \\
\hline FR-34/15E/10-0587 & -- & 1,510 & -- & 61 & 2 \\
\hline FR-34/15E/10-0652 & $05-27-82$ & 1,490 & 1,480 & 11 & 3 \\
\hline FR-34/15E/10-0373 & $10-25-74$ & 1,480 & 1,440 & 120 & 3 \\
\hline FR-34/15E/12-0061 & $06-22-67$ & 1,450 & 1,395 & 116 & 4 \\
\hline FR-35/13E/34-0227 & -. & 1,630 & -- & 36 & -- \\
\hline FR-35/16E/18-0069 & $09-28-66$ & 1,400 & 1,395 & 45 & 5 \\
\hline FR-35/16E/18-0068 & $09-26-66$ & 1,400 & 1,386 & 54 & 5 \\
\hline FR-35/16E/24-0570 & $11-04-81$ & 1,310 & 1,294 & 20 & 3 \\
\hline FR-35/16E/34-0571 & $11-04-81$ & 1,360 & 1,354 & 22 & 3 \\
\hline FR-34/16E/16-0572 & $11-04-81$ & 1,320 & 1,313 & 23 & 3 \\
\hline FR-34/16E/24-0573 & $11-04-81$ & 1,340 & 1,281 & 82 & 3 \\
\hline
\end{tabular}

${ }^{1}$ U.S. Geological Survey observation well constructed for this study. 
Appendix B. Horizontal hydraulic conductivity, well-construction data, and brief description of geologic materials at observation wells

[ft, feet]

\begin{tabular}{|c|c|c|c|c|c|c|}
\hline Local well number & $\begin{array}{l}\text { Horizontal } \\
\text { hydraulic } \\
\text { conductivity } \\
\text { (feet per day) }\end{array}$ & $\begin{array}{l}\text { Depth of } \\
\text { observation } \\
\text { well } \\
\text { (feet) }\end{array}$ & $\begin{array}{l}\text { Screen } \\
\text { length } \\
\text { (feet) }\end{array}$ & & & ithology from test boring \\
\hline FR-35/15E/23-0565 & 0.4 & 27 & 3.0 & $\begin{array}{c}0-3 \\
3-8 \\
8-18 \\
18-23 \\
23-28\end{array}$ & $\begin{array}{l}\mathrm{ft} \\
\mathrm{ft} \\
\mathrm{ft} \\
\mathrm{ft} \\
\mathrm{ft}\end{array}$ & $\begin{array}{l}\text { silt and clay } \\
\text { silt and clay with coarse gravel } \\
\text { sand and gravel } \\
\text { fine sand with gravel } \\
\text { clay and sand }\end{array}$ \\
\hline FR-35/15E/36-0566 & 48 & 22 & 3.0 & $\begin{array}{r}0-18 \\
13-18 \\
18-23\end{array}$ & $\begin{array}{l}\mathrm{ft} \\
\mathrm{ft} \\
\mathrm{ft}\end{array}$ & $\begin{array}{l}\text { fine sand with very coarse gravel } \\
\text { coarse sand with some gravel } \\
\text { coarse sand }\end{array}$ \\
\hline FR-36/13E/14-0567 & 1.6 & 63 & 1.3 & $\begin{array}{c}0-3 \\
3-13 \\
13-30 \\
30-43 \\
43-58 \\
58-63\end{array}$ & $\begin{array}{l}\mathrm{ft} \\
\mathrm{ft} \\
\mathrm{ft} \\
\mathrm{ft} \\
\mathrm{ft} \\
\mathrm{ft}\end{array}$ & $\begin{array}{l}\text { clay } \\
\text { clay and silt } \\
\text { sand } \\
\text { sand and clay } \\
\text { clay } \\
\text { sand and clay }\end{array}$ \\
\hline FR-36/13E/26-0568 & 1.5 & 58 & 3.0 & $\begin{array}{r}0-13 \\
13-18 \\
18-53 \\
53-58\end{array}$ & $\begin{array}{l}\mathrm{ft} \\
\mathrm{ft} \\
\mathrm{ft} \\
\mathrm{ft}\end{array}$ & $\begin{array}{l}\text { silt and clay } \\
\text { sand and gravel } \\
\text { sand } \\
\text { silt and sand }\end{array}$ \\
\hline FR-35/16E/24-0570 & 1.3 & 20 & 3.0 & $\begin{array}{l}0-3 \\
3-23\end{array}$ & $\begin{array}{l}\mathrm{ft} \\
\mathrm{ft}\end{array}$ & $\begin{array}{l}\text { silt and sand } \\
\text { fine sand with gravel }\end{array}$ \\
\hline FR-35/16E/34-0571 & 9.2 & 22 & 3.0 & $\begin{array}{l}0-4 \\
4-24\end{array}$ & $\begin{array}{l}\mathrm{ft} \\
\mathrm{ft}\end{array}$ & $\begin{array}{l}\text { silt and sand } \\
\text { silt and coarse sand }\end{array}$ \\
\hline FR-34/16E/16-0572 & 24 & 23 & 3.0 & $\begin{array}{r}0-13 \\
13-18 \\
18-23\end{array}$ & $\begin{array}{l}\mathrm{ft} \\
\mathrm{ft} \\
\mathrm{ft}\end{array}$ & $\begin{array}{l}\text { sand and gravel } \\
\text { silt and coarse sand } \\
\text { coarse sand }\end{array}$ \\
\hline FR-34/16E/24-0573 & 8.0 & 82 & 1.3 & $\begin{array}{r}0-43 \\
43-48 \\
48-83\end{array}$ & $\begin{array}{l}\mathrm{ft} \\
\mathrm{ft} \\
\mathrm{ft}\end{array}$ & $\begin{array}{l}\text { sand and gravel } \\
\text { medium sand } \\
\text { fine sand }\end{array}$ \\
\hline FR-35/15E/32-0596 & 8.6 & 21 & 3.0 & $0-23$ & $\mathrm{ft}$ & clay with lenses of sand and gravel \\
\hline
\end{tabular}


Appendix C. Physical and chemical characteristics of water from wells on the Potawatomi Indian Reservation

$\left[\mu \mathrm{S} / \mathrm{cm}\right.$, microsiemens per centimeter at 25 degrees Celsius; $\mathrm{mg} / \mathrm{L}$, milligrams per liter; ${ }^{\circ} \mathrm{C}$, degrees Celsius; -- , no data available; <, less than. The five digit number ending each column heading is the parameter code used in the U.S. Geological Survey's Water Data Storage and Retrieval System.]

\begin{tabular}{|c|c|c|c|c|c|c|c|c|}
\hline Local identifier & Site number & Date & Time & $\begin{array}{c}\text { Depth of } \\
\text { well, } \\
\text { total } \\
\text { (feet) } \\
(72008)\end{array}$ & $\begin{array}{c}\text { Depth to } \\
\text { bottom of } \\
\text { sample } \\
\text { interval } \\
\text { (feet) } \\
(72016)\end{array}$ & $\begin{array}{l}\text { Depth to } \\
\text { top of } \\
\text { sample } \\
\text { interval } \\
\text { (feet) } \\
(72015) \\
\end{array}$ & $\begin{array}{c}\text { Elevation } \\
\text { of land- } \\
\text { surface } \\
\text { datum } \\
\text { (feet } \\
\text { above } \\
\text { NGVD) } \\
(72000) \\
\end{array}$ & $\begin{array}{c}\text { Specific } \\
\text { conductance } \\
(\mu \mathrm{S} / \mathrm{cm}) \\
(00095) \\
\end{array}$ \\
\hline FR-36/13E/35-0581 & 452331088495201 & $08-09-82$ & 1010 & 165.00 & 165 & 161 & 1,755 & 615 \\
\hline FR-34/15E/28-0579 & 452405088380701 & $08-10-82$ & 0830 & 96.00 & 96 & 86 & 1,570 & 540 \\
\hline FR-34/15E/28-0588 & 452408088380201 & $05-17-83$ & 1300 & 110.00 & -- & -- & 1,560 & 205 \\
\hline FR-36/15E/28-0589 & 452425088380601 & $05-17-83$ & 1100 & 74.00 & -- & -- & 1,560 & 510 \\
\hline FR-34/15E/28-0580 & 452459088375501 & $08-10-82$ & 0900 & 95.00 & 95 & 81 & 1,510 & 280 \\
\hline${ }^{1}$ FR-34/16E/24-0573 & 452509088255601 & $08-31-82$ & 1130 & 83.00 & -- & -- & 1,340 & 155 \\
\hline${ }^{1} \mathrm{FR}-34 / 16 \mathrm{E} / 16-0572$ & 452515088294001 & $08-31-82$ & 1030 & 23.00 & -- & -- & 1,320 & 165 \\
\hline FR-34/15E/16-0578 & 452536088380401 & $05-17-83$ & 1000 & 43.00 & -- & -- & 1,555 & 660 \\
\hline FR-34/15E/10-0587 & 452651088362801 & $08-10-82$ & 1005 & 61.00 & 61 & 59 & 1,510 & 270 \\
\hline 'FR-35/16E/34-0571 & 452802088290901 & $08-31-82$ & 1245 & 24.00 & -- & - & 1,360 & 195 \\
\hline FR-35/15E/28-0576 & 452932088364801 & 08-09-82 & 1525 & 129.00 & 129 & 126 & 1,545 & 250 \\
\hline${ }^{1} \mathrm{FR}-35 / 15 E / 23-0565$ & 452934088345101 & $08-31-82$ & 0915 & 27.00 & -- & -- & 1,480 & 210 \\
\hline FR-35/15E/22-0577 & 453004088364001 & $08-09-82$ & 1445 & 146.00 & 146 & 143 & 1,595 & 250 \\
\hline FR-36/13E/35-0463 & 453327088493301 & $08-09-82$ & 1005 & 35.00 & -- & -. & 1,870 & 230 \\
\hline FR-36/13E/35-0582 & 453327088493302 & $08-08-83$ & 1500 & 331.00 & -- & -- & 1,875 & 190 \\
\hline FR-36/13E/35-0586 & 453333088495201 & $08-09-82$ & 0915 & 243.00 & 243 & 237 & 1,800 & 280 \\
\hline FR-36/13E/34-0584 & 453345088505401 & $08-09-82$ & 1400 & 216.00 & 216 & 213 & 1,830 & 255 \\
\hline FR-36/13E/36-0574 & 453350088490301 & $08-09-82$ & 1135 & 228.00 & 228 & 222 & 1,780 & 280 \\
\hline FR-36/13E/36-0592 & 453354088490701 & $05-17-83$ & 0840 & 151.00 & -- & -- & 1,770 & 165 \\
\hline FR-36/13E/27-0585 & 453401088513401 & $08-09-82$ & 1335 & 253.00 & 253 & 250 & 1,870 & 240 \\
\hline${ }^{1} \mathrm{FR}-36 / 13 \mathrm{E} / 26-0568$ & 453412088494301 & $08-30-82$ & 1415 & 58.00 & -- & -- & 1,680 & 210 \\
\hline \multirow[t]{2}{*}{ FR-36/13E/26-0575 } & 453421088494701 & $08-09-82$ & 1210 & 118.00 & - & - & 1,715 & 210 \\
\hline & & $08-08-83$ & 1545 & 118.00 & -- & -- & 1,715 & 280 \\
\hline
\end{tabular}


Appendix C. Physical and chemical characteristics of water from wells on the Potawatomi Indian Reservation--Continued

\begin{tabular}{|c|c|c|c|c|c|c|c|}
\hline Local identifier & $\begin{array}{c}\mathrm{pH} \\
\text { (standard } \\
\text { units) } \\
(00400) \\
\end{array}$ & $\begin{array}{c}\text { Temperature, } \\
\text { water, } \\
\text { (degrees } \\
\text { Celsius) } \\
(00010) \\
\end{array}$ & $\begin{array}{l}\text { Hardness, } \\
\text { total } \\
(\mathrm{mg} / \mathrm{L} \\
\left.\text { as } \mathrm{CaCO}_{3}\right) \\
(00900) \\
\end{array}$ & $\begin{array}{c}\text { Calcium, } \\
\text { dissolved } \\
\text { (mg/L } \\
\text { as Ca) } \\
(00915)\end{array}$ & $\begin{array}{l}\text { Magnesium, } \\
\text { dissolved } \\
\text { (mg/L } \\
\text { as } \mathrm{Mg}) \\
(00925) \\
\end{array}$ & $\begin{array}{c}\text { Sodium, } \\
\text { dissolved } \\
(\mathrm{mg} / \mathrm{L} \\
\text { as } \mathrm{Na}) \\
(00930)\end{array}$ & $\begin{array}{c}\text { Potassium, } \\
\text { dissolved } \\
\text { (mg/L } \\
\text { as K } \\
(00935) \\
\end{array}$ \\
\hline FR-36/13E/35-0581 & 7.8 & 9.5 & 300 & 66 & 33 & 4.5 & 0.70 \\
\hline FR-34/15E/28-0579 & 7.9 & 9.5 & 250 & 58 & 25 & 6.3 & 1.4 \\
\hline FR-34/15E/28-0588 & 8.6 & 8.0 & 120 & 30 & 10 & 6.8 & 1.5 \\
\hline FR-36/15E/28-0589 & 7.7 & 9.5 & 350 & 80 & 37 & 8.6 & 2.0 \\
\hline FR-34/15E/28-0580 & 7.8 & 10.0 & 130 & 31 & 13 & 3.1 & .80 \\
\hline 'FR-34/16E/24-0573 & 9.3 & 10.0 & 84 & 20 & 8.3 & 1.8 & .80 \\
\hline 'FR-34/16E/16-0572 & 7.5 & 10.5 & 79 & 23 & 5.3 & 1.7 & .90 \\
\hline FR-34/15E/16-0578 & 7.3 & 11.5 & 490 & 110 & 53 & 26 & 3.7 \\
\hline FR-34/15E/10-0587 & 8.0 & 8.0 & 140 & 31 & 14 & 2.5 & 1.6 \\
\hline 'FR-35/16E/34-0571 & 7.3 & 10.0 & 98 & 26 & 8.0 & 1.2 & 1.2 \\
\hline FR-35/15E/28-0576 & 8.2 & 10.0 & 120 & 27 & 12 & 2.9 & 1.5 \\
\hline 'FR-35/15E/23-0565 & 8.1 & 8.5 & 120 & 27 & 12 & 2.8 & 2.0 \\
\hline FR-35/15E/22-0577 & 8.2 & 9.0 & 120 & 28 & 12 & 3.2 & 1.3 \\
\hline FR-36/13E/35-0463 & 8.0 & 10.0 & 130 & 28 & 14 & 1.9 & .50 \\
\hline FR-36/13E/35-0582 & 8.4 & 15.0 & -- & -- & -- & -- & -- \\
\hline FR-36/13E/35-0586 & 8.1 & 9.5 & 150 & 32 & 17 & 1.9 & .50 \\
\hline FR-36/13E/34-0584 & 8.0 & 9.5 & 120 & 28 & 13 & 2.4 & .60 \\
\hline FR-36/13E/36-0574 & 8.1 & 9.5 & 140 & 31 & 15 & 1.9 & .40 \\
\hline FR-36/13E/36-0592 & 7.9 & 13.5 & 130 & 29 & 14 & 3.2 & .80 \\
\hline FR-36/13E/27-0585 & 8.2 & 9.5 & 130 & 29 & 14 & 2.3 & .60 \\
\hline 'FR-36/13E/26-0568 & 7.6 & 9.0 & 160 & 37 & 17 & 4.9 & 2.5 \\
\hline FR-36/13E/26-0575 & 8.1 & 9.0 & 150 & 33 & 16 & 2.1 & .50 \\
\hline & 8.2 & - & -- & -- & -- & -- & -- \\
\hline Local identifier & $\begin{array}{c}\text { Alkalinity, } \\
\text { laboratory } \\
(\mathrm{mg} / \mathrm{L} \\
\left.\text { as } \mathrm{CaCO}_{3}\right) \\
(90410) \\
\end{array}$ & $\begin{array}{c}\text { Sulfate, } \\
\text { dissolved } \\
(\mathrm{mg} / \mathrm{L} \\
\left.\text { as } \mathrm{SO}_{4}\right) \\
(00945)\end{array}$ & $\begin{array}{c}\text { Chloride, } \\
\text { dissolved } \\
(\mathrm{mg} / \mathrm{L} \\
\text { as Cl) } \\
(00940)\end{array}$ & $\begin{array}{c}\text { Fluoride, } \\
\text { dissolved } \\
\text { (mg/L } \\
\text { as F) } \\
(00950)\end{array}$ & $\begin{array}{c}\text { Silica, } \\
\text { dissolved } \\
(\mathrm{mg} / \mathrm{L} \\
\left.\text { as } \mathrm{SiO}_{2}\right) \\
(00955)\end{array}$ & $\begin{array}{c}\text { Solids, } \\
\text { residue, } \\
\text { at } 180^{\circ} \mathrm{C} \\
\text { dissolved } \\
(\mathrm{mg} / \mathrm{L}) \\
(70300) \\
\end{array}$ & $\begin{array}{l}\text { Nitrogen, } \\
\mathrm{NO}_{3}+\mathrm{NO}_{2}, \\
\text { dissolved } \\
(\mathrm{mg} / \mathrm{L} \\
\text { as } \mathrm{N}) \\
(00631) \\
\end{array}$ \\
\hline FR-36/13E/35-0581 & 221 & 10 & 25 & -- & 14 & 388 & 15.0 \\
\hline FR-34/15E/28-0579 & 147 & 18 & 59 & -- & 15 & 346 & 4.40 \\
\hline FR-34/15E/28-0588 & 121 & 2.0 & 5.0 & .80 & 10 & 136 & -- \\
\hline FR-36/15E/28-0589 & 242 & 14 & 78 & .10 & 15 & 420 & -- \\
\hline FR-34/15E/28-0580 & 112 & 6.0 & 11 & -- & 13 & 161 & .660 \\
\hline 'FR-34/16E/24-0573 & 79 & 7.0 & 1.6 & .10 & 2.4 & 107 & $<.100$ \\
\hline 'FR-34/16E/16-0572 & 83 & 8.0 & 2.1 & .10 & 3.9 & 114 & .430 \\
\hline FR-34/15E/16-0578 & 318 & 18 & 53 & .10 & 17 & 595 & -- \\
\hline FR-34/15E/10-0587 & 123 & 14 & .60 & -- & 11 & 156 & $<.100$ \\
\hline 'FR-35/16E/34-0571 & 111 & 5.0 & 1.8 & .10 & 14 & 146 & $<.100$ \\
\hline FR-35/15E/28-0576 & 113 & 12 & .80 & -- & 14 & 127 & $<.100$ \\
\hline 'FR-35/15E/23-0565 & 103 & 11 & .70 & .10 & 16 & 131 & .110 \\
\hline FR-35/15E/22-0577 & 114 & 13 & 1.0 & -- & 13 & 142 & .150 \\
\hline FR-36/13E/35-0463 & 122 & 7.0 & .70 & -- & 13 & 127 & .270 \\
\hline FR-36/13E/35-0582 & -- & .. & -- & - & -- & -- & -. \\
\hline FR-36/13E/35-0586 & 142 & 6.0 & 1.0 & -- & 13 & 151 & .250 \\
\hline FR-36/13E/34-0584 & 117 & 8.0 & 3.2 & -- & 13 & 149 & .290 \\
\hline FR-36/13E/36-0574 & 133 & 6.0 & 1.3 & -- & 14 & 149 & .800 \\
\hline FR-36/13E/36-0592 & 125 & 12 & 1.8 & .10 & 14 & 154 & -- \\
\hline FR-36/13E/27-0585 & 122 & 9.0 & 2.9 & -- & 12 & 140 & .300 \\
\hline 'FR-36/13E/26-0568 & 144 & 8.0 & 9.9 & $<.10$ & 16 & 202 & .370 \\
\hline \multirow[t]{2}{*}{ FR-36/13E/26-0575 } & 131 & 12 & 2.6 & -- & 13 & 170 & 1.30 \\
\hline & -- & -- & -- & -- & -- & -- & -- \\
\hline
\end{tabular}

' U.S. Geological Survey observation well constructed for this study. 


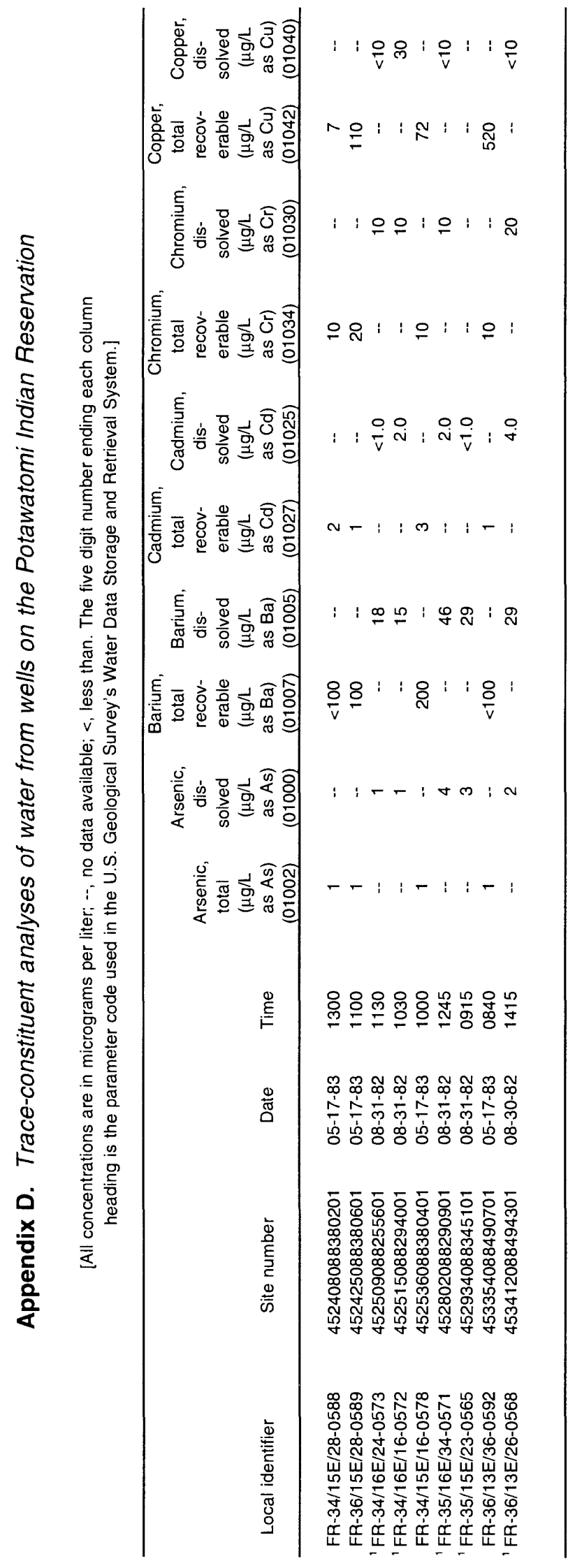

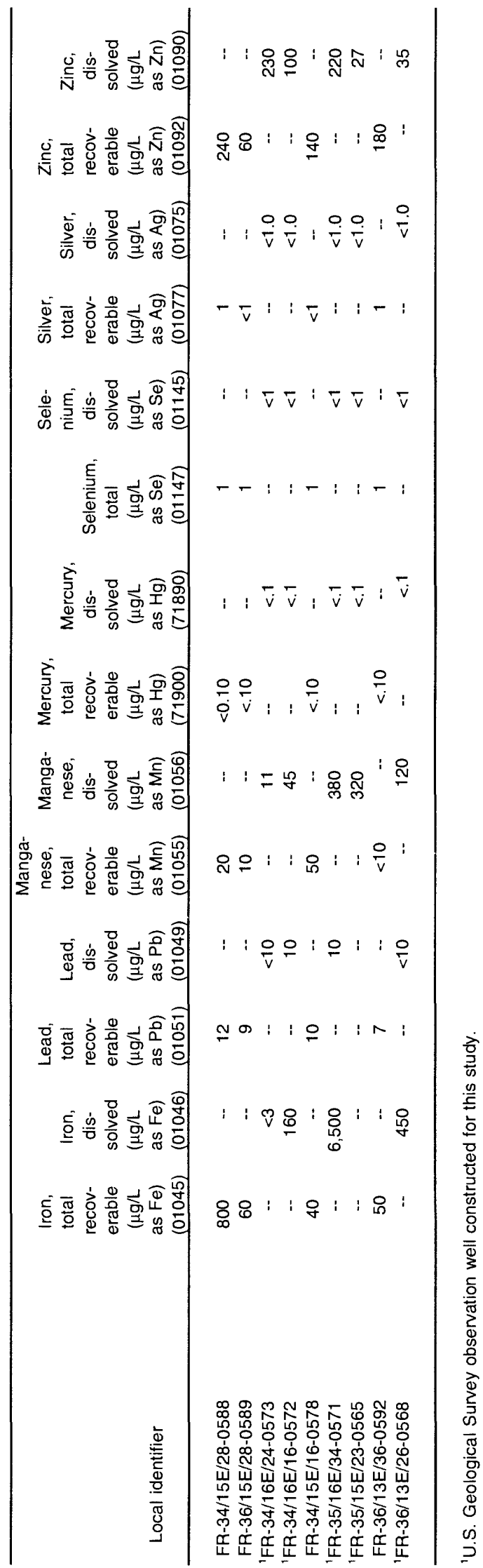




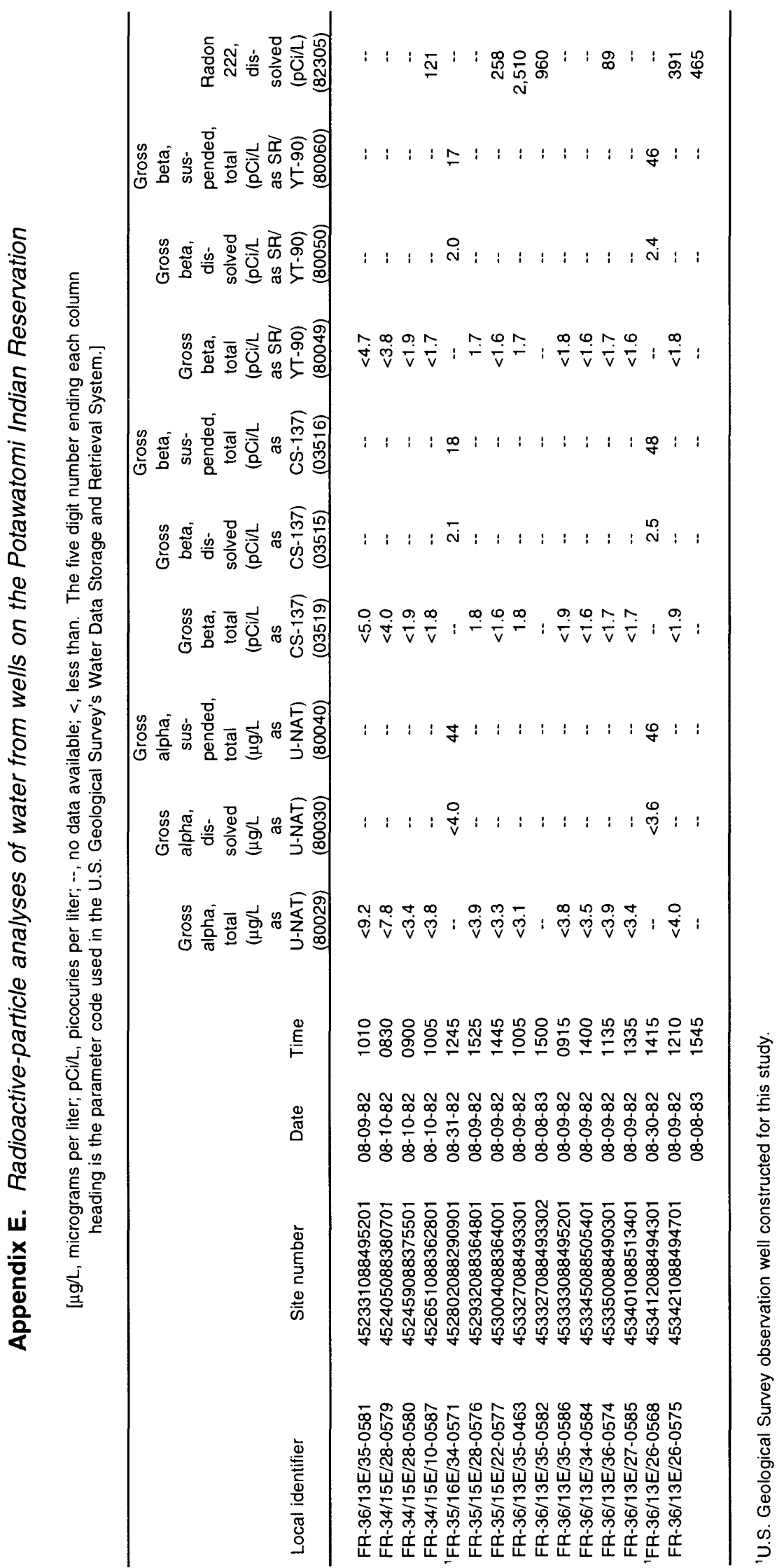




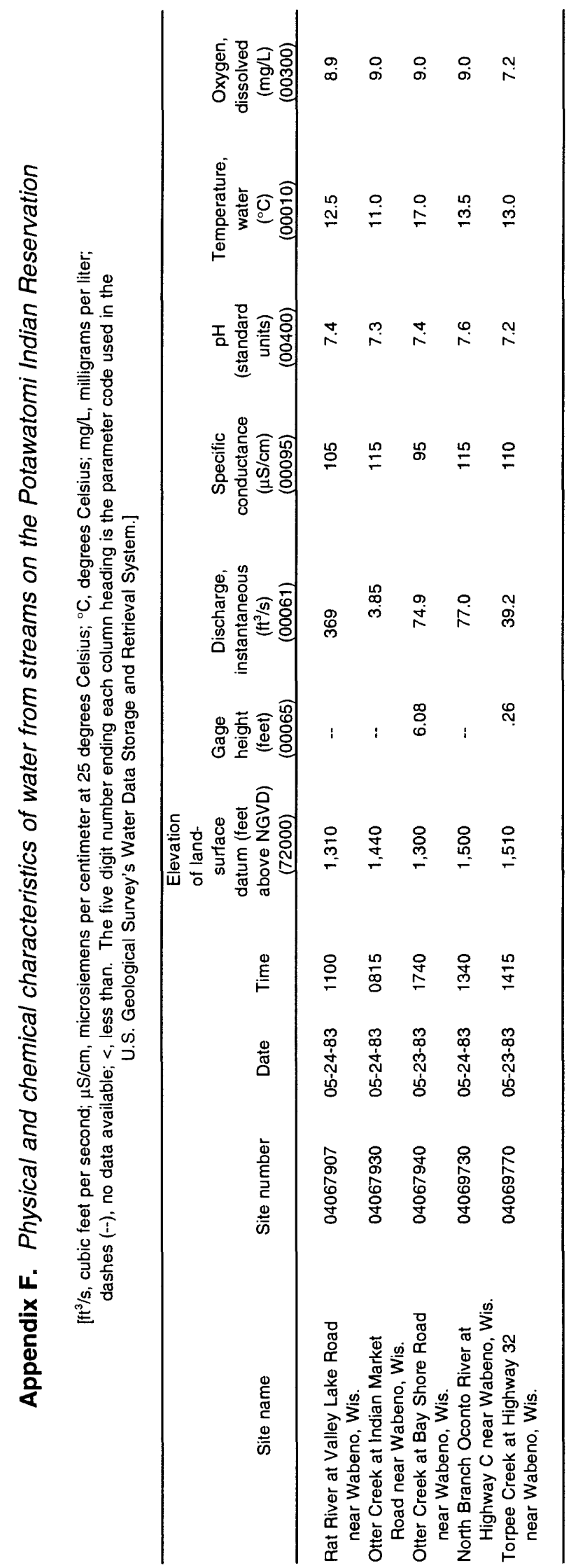

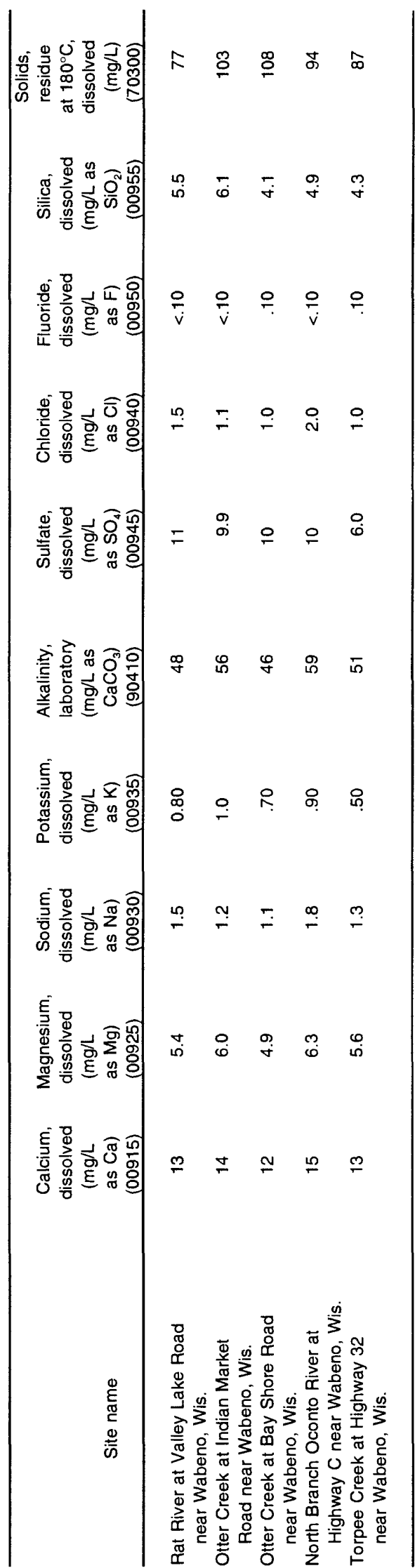




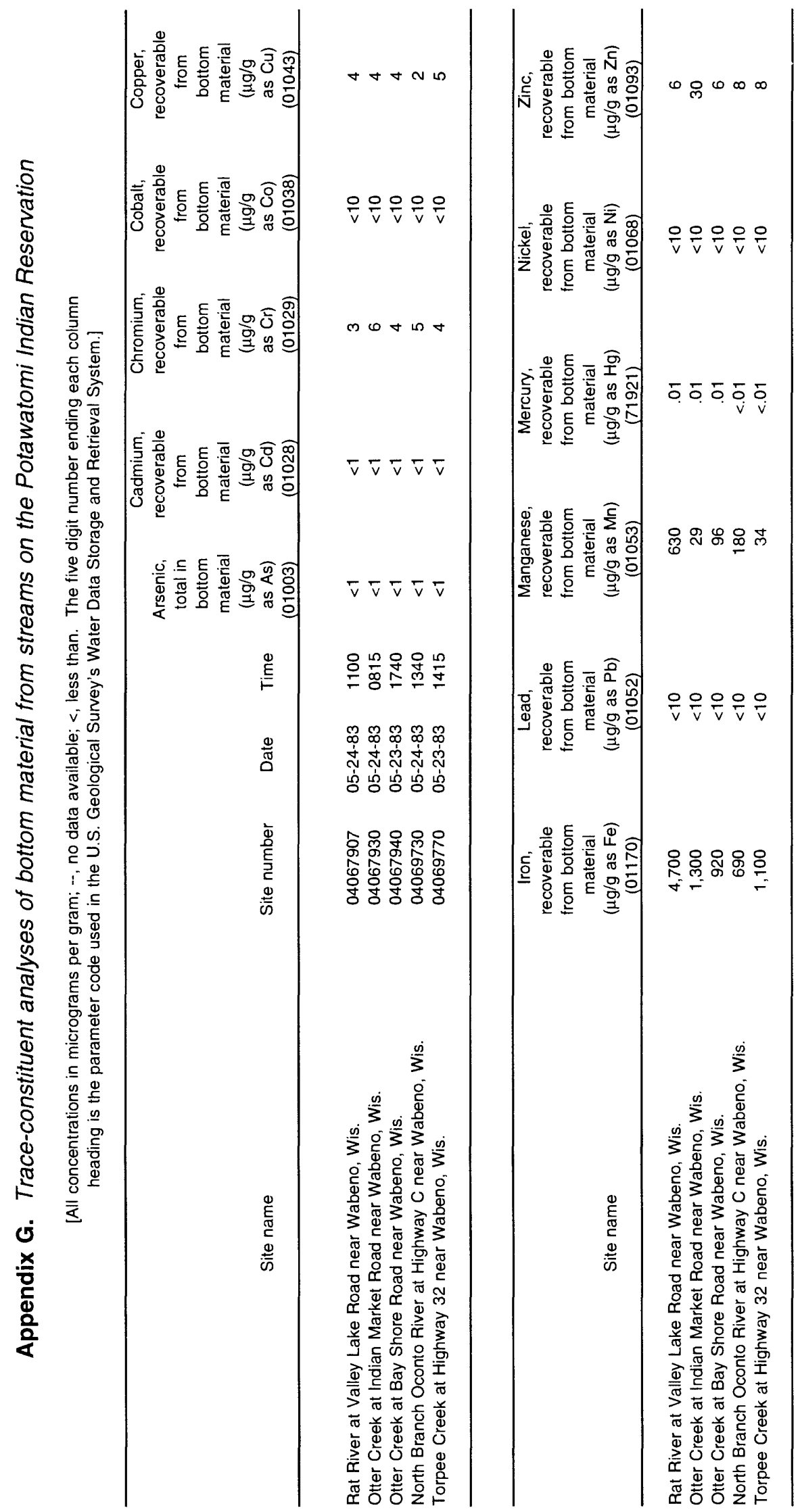




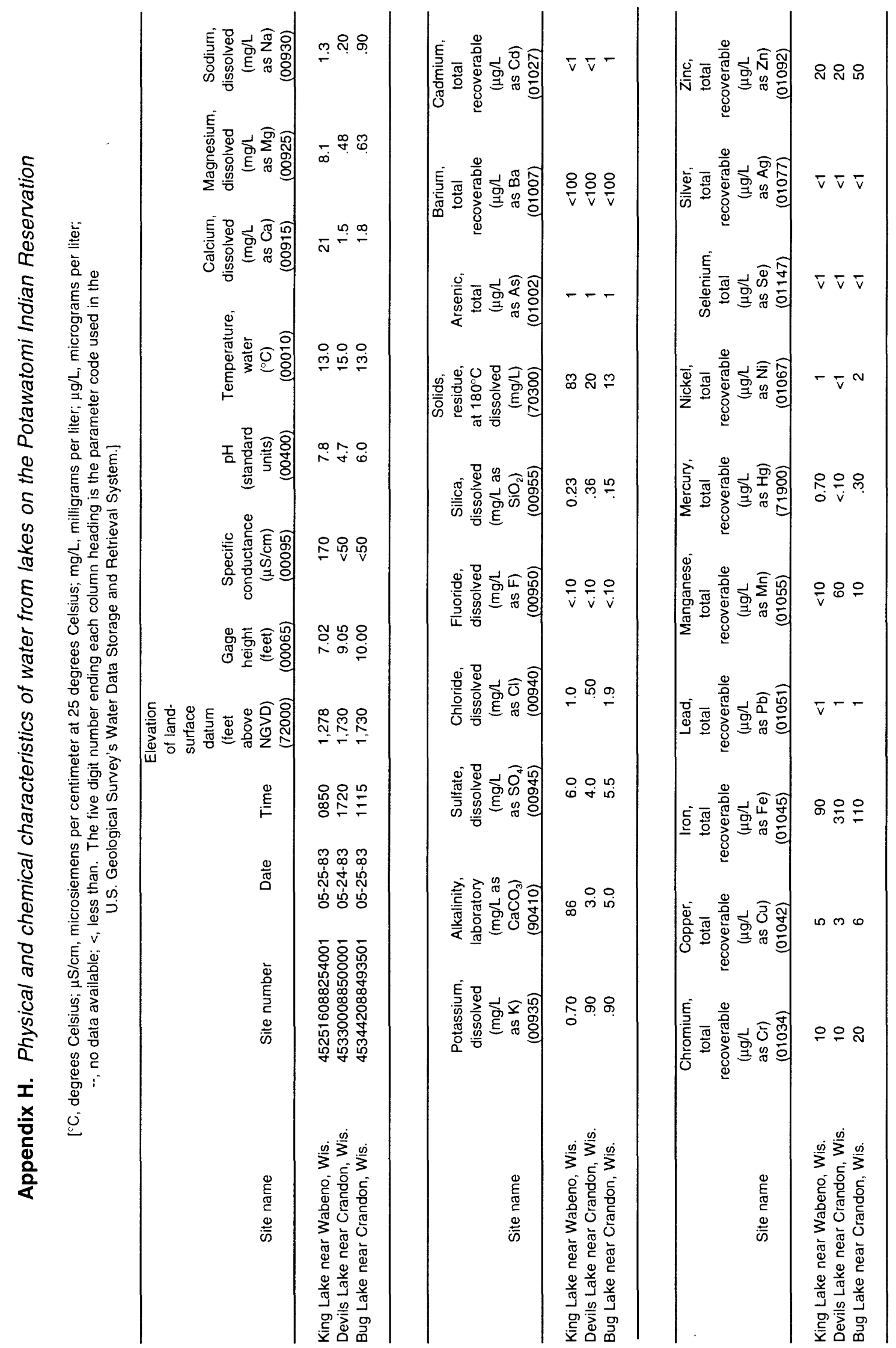

